\title{
An Unusual Presentation of Altered Thyroid in Male
}

\author{
Dr Avinash Shankar ${ }^{1}$, Dr Amresh Shankar², Dr Anuradha Shankar ${ }^{3}$ \\ ${ }^{1} \mathrm{MBBS}$ (MGIMS); MD (Internal Medicine); DNB (E\&M), Postgraduate in Endocrinology \& Metabolism \\ (AIIMS Delhi), Chairman, National Institute of Health \& Research, Warisaliganj (Nawada) Bihar, 805130 \\ ${ }^{2}$ BAMS (BRABU); MBA (HA), State Health Services, Government of Bihar, Director (Hon), Aarogyam \\ Punarjeevan, Ara Garden Road, Jagdeopath, Baily Road, Patna 14, 800014 \\ ${ }^{3}$ BAMS (BRABU), Director, Centre for Indigenous Medicine \& Research, RA Hospital \& Research Centre, \\ Warisaliganj (Nawada) \\ *Corresponding Author: Dr Avinash Shankar, MBBS (MGIMS); MD (Internal Medicine); DNB (E\& M), \\ Postgraduate in Endocrinology \& Metabolism (AIIMS Delhi), Chairman, National Institute of Health \& \\ Research, Warisaliganj(Nawada) Bihar, 805130
}

Abstract: Altered thyroid function is more common among female and hypothyroidism predominate with clinical features of Weight gain, asthenia due to declined oestrogen in female and declined testosterone in male resulting lowered BMR yielding subcutaneous accumulation ofmucin and retention of water and electrolytes.

But in the present study male presenting with high TSH, low thyroxin (T4) and normal testosterone presented with body weight less than ideal body weight while person with low TSH, raised thyroxin (T4) and low testosterone presented with weight more than Ideal body weight. None was having any other pathology.

This study suggest that weight gain or weight loss is secondary to gonadal hormone oestrogen or testosterone which affect BMR and subcutaneous accumulation ofmucin or loss of subcutaneous fat. Hence weight gain or weight loss is an effect of altered BMR not the thyroid hormone directly.

Keywords: Hypothyroidism, Hyperthyroidism, TSH, Testosterone, BMR, Subcutaneous deposit, Ideal body weight

\section{INTRODUCTION}

Endocrinal disorder's incidence is increasing in geometric progression and alteration in thyroid function remain prime $\left({ }^{1,2}\right)$. Altered thyroid function presents as hypothyroidism and hyperthyroidism, out of which hypothyroidism is very common. Hypothyroidism affects more female than male ${ }^{(3,4)}$ and commonest presenting features as

Weight gain, asthenia, constipation, lowers sexual function, alters spermiogenesis and may yield erectile dysfunction due to altered testosterone in male while hyperthyroidism manifest as weight loss, eye ball prominence, hair fall etc ${ }^{(5,6)}$

Presentation of hypothyroidism and hyperthyroidism can be summarised as -

\begin{tabular}{|c|c|c|}
\hline & yroidis m & Hyperthyroidism \\
\hline & Weight gain & weight loss \\
\hline$\cdot$ & Fatigue & increased appetite \\
\hline • & Sensitivity to cold temperatures & nervousness \\
\hline$\cdot$ & Depression & restlessness \\
\hline$\bullet$ & Dry skin & inability to concentrate \\
\hline$\cdot$ & Thinning hair & weakness \\
\hline • & Heavy menstrual periods (in female ) & irregular heartbeat \\
\hline$\cdot$ & Trouble sleeping & difficulty in sleeping \\
\hline$\cdot$ & Difficulty concentrating & fine, brittle hair \\
\hline$\bullet$ & Pain or swelling of the joints & itching \\
\hline • & Constipation & hair loss \\
\hline & High choles terol levels & nausea and vomiting \\
\hline & Muscle weakness & breast development in men \\
\hline
\end{tabular}


Presentation of weight loss in hypothyroidism male with raised TSH, low thyroxin $\left(\mathrm{T}_{4}\right)$ and weight gain in raised Thyroxin $\left(\mathrm{T}_{4}\right)$ and very low TSH ,created an eagerness to analyse the situation to adjudge the etio pathogenesis of presenting features in persons with altered thyroid function .

These days increasing incidence of hypothyroidism even in male and presentation adverse to usual manifestations, needed due documentation and analysis for our future reference.

\section{MATERIAL \& Methods}

Objective of study: To establish reason of variability of myxoedema in hypothyroid and hyperthyroid state. In male with variable testosterone level.

\subsection{Mate rial}

Cases presenting with varied presentation and shoeing high TSH been selected and analysed at RA. Hospital \& Research Centre Warisaliganj and Centre for Endocrine and Metabolism, Aarogyam Punarjeevan, Ram Bhawan, Ara Garden Road, Jagdeo path, Baily Road Patna 14.

Case 1: Male Hindu aged 25 yrs, non-vegetarian, average built resident of, Manglam Bihar Apartment, Ara Graden, Patna 14 presented with -

Marked debility, Exertional Heaviness in the chest, Sleeplessness, leg cramps, uneasiness

Pain in chest, loss of appetite, general debility

Afebrile, Systemic examination shows no abnormality No muscle stiffness, No myxoedema

Blood pressure 100/60 mm Hg, Blood Sugar: Random 123 mg \%; $\mathrm{HbA}_{1} \mathrm{C}: 5.7$

Serum Cholesterol Normal Thyroid Function: TSH 18.11uIU/L, $\mathrm{T}_{4}: 7.6 \mathrm{ug} / \mathrm{dl}$

Vitamin D- 21.68ng/dl Vitamin $B_{12}$ low, Serum Calcium: $8.83 \mathrm{mg} / \mathrm{dl}$

Srum Testosterone: Normal 481ug/dl

ECG: Low voltage

Urine: RBC +, Albumin ++

Case2:

A 45 yrs male pure vegetarian resident of Old Bank Road, Warisaliganj (Nawada), average built complains of progressive decline weight, loss of appetite, general debility, uneasiness, constipation, occasional heaviness in the chest on strenuous exertion

BP: 100/50 mm Hg, Blood Sugar: (F) 78mg\%; (PP): 123 mg \% Serum Cholesterol - N,

TSH 28.12uIU/L, T4: $7.2 \mathrm{ug} / \mathrm{dl}$

HbA1C: 5.2 Serum Testosterone 540

ECG Low voltage tracing

Case No: 3

A Mohamden male aged 43 years resident of Takya par Warisaliganj (Nawada), Weight $89 \mathrm{Kg}$, nonvegetarian, pain in chest, pain in abdomen, vertigo, exertional dyspnoea

Seum TSH 0.1 IU/dl; T4: 14ug/dl Serum testosterone 168

Blood pressure 140/80 mm Hg; Blood sugar(F) : 80mg\% , HbA1C : 5.0

Serum Calcium: Vitamin D3: $18.4 \mathrm{ng} / \mathrm{dl}$

ECG: Normal sinus rhythm 
Case 04:

A 52 yrs old Hindu male presenting with weight gain, exertional dyspnoea, occasional pain in chest non vegetarian presented with -

Body weight: $86 \mathrm{Kg}$, Blood pressure: 150/100 mm Hg; HbA1C: 4.9

Thyroid profile: TSH: 3.17uIU/dl; T4: $12.2 \mathrm{ug} / \mathrm{dl}$; Serum Calcium 10.12mg\%

Serum testosterone: $294.95 \mathrm{ng} / \mathrm{dl}$; Vitamin D: $17.52 \mathrm{ng} / \mathrm{dl}$

ECG: Normal tracing

\subsection{Method}

All the three persons presenting with altered manifestation been clinically examined and thoroughly investigated for other possible adjuvant presentation responsible for the altered presentations.

Patients were adjudged for altered thyroid state as per -

\begin{tabular}{|l|l|l|}
\hline Paramters & & interpretation \\
\hline TSH & Thyroxin (T4) & Thyroid function \\
\hline Normal & Normal & Normal thyroid function \\
\hline Raised & Normal & Subclinical hypothyroidism \\
\hline Raised & Low & Overt hypothyroidism \\
\hline Low/ Normal & Low & Central hypothyroidism \\
\hline Very Low & High & Hyperthyroidism \\
\hline
\end{tabular}

Based on the value of thyroxin (T4) and Thyroid stimulating Hormone (TSH) level hypothyroidism been categorized as -

\begin{tabular}{|c|c|}
\hline Types of hypothyroid state & Characteristics \\
\hline Central: & $\begin{array}{l}\text { If the TSH level is normal or low and serum free T4 } \\
\text { levels are low, this is suggestive of central } \\
\text { hypothyroidism (not enough TSH or TRH secretion } \\
\text { by the pituitary gland or hypothalamus). There may be } \\
\text { other features of hypopituitarism, such as menstrual } \\
\text { cycle abnormalities and adrenal insufficiency. There } \\
\text { might also be symptoms of a pituitary mass such as } \\
\text { headaches and vision changes. Central } \\
\text { hypothyroidism should be investigated further to } \\
\text { determine the underlying cause }\end{array}$ \\
\hline Overt: & $\begin{array}{l}\text { TSH levels are high and T4 and T3 levels are low. } \\
\text { Overt hypothyroidism may also be diagnosed in those } \\
\text { who have a TSH on multiple occasions of greater than } \\
5 \mu \mathrm{U} / \mathrm{L} \text {, appropriate symptoms, and only a borderline } \\
\text { low T4. It may also be diagnosed in those with a TSH } \\
\text { of greater than } 10 \mu \mathrm{U} / \mathrm{L}\end{array}$ \\
\hline Sub clinical & 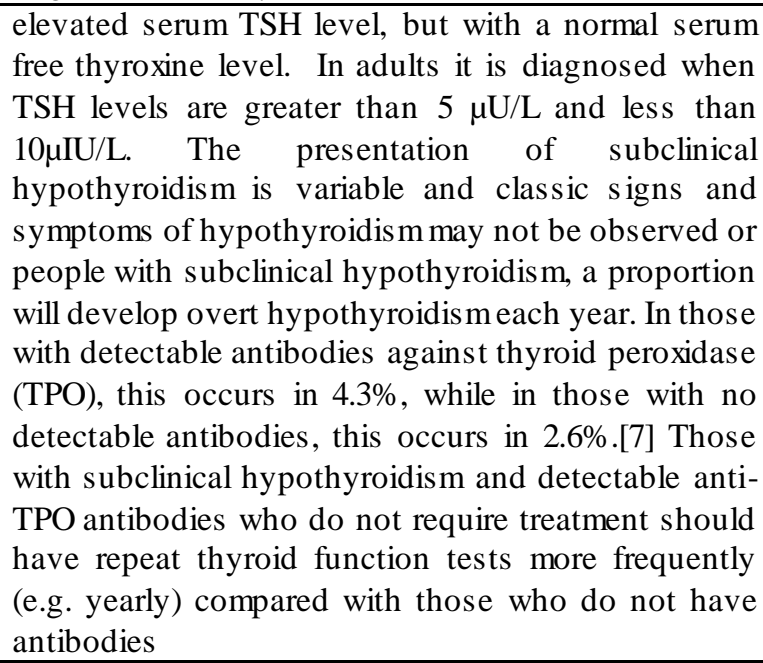 \\
\hline
\end{tabular}




\section{OBSERVATION}

Both cases (Case $1 \& 2$ ) shows all the findings suggestive of hypothyroidism but not weight gain Or myxoedema rather weight loss while $3^{\text {rd }}$ and $4^{\text {th }}$ cases having hyperthyroidic state present with myxoedema and weight gain.

In both Case 1 and 2, serum testosterone remained in normal range with low voltage ECG while in $3^{\text {rd }}$ and $4^{\text {th }}$ cases serum testosterone was lower than normal, with normal ECG and blood sugar status was normal in all the 4 cases

\begin{tabular}{|c|c|c|c|c|}
\hline Particulars & Case I & Case II & Case III & Case IV \\
\hline Age (in years) & 29 & 45 & 43 & 52 \\
\hline Body weight (in $\mathrm{Kg}$ ) & 42 & 53 & 89 & 86 \\
\hline Blood pressure(mmHg) & $100 / 60$ & $100 / 50$ & $140 / 80$ & $150 / 100$ \\
\hline TSH $(\mu \mathrm{IU} / \mathrm{dL})$ & 18.11 & 28.12 & 0.1 & 3.17 \\
\hline 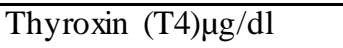 & 7.6 & 7.2 & 14 & 12.2 \\
\hline Blood Sugar (mg\%) & $123(\mathrm{R})$ & $123(\mathrm{PP})$ & $80(\mathrm{~F})$ & 132(PP) \\
\hline $\mathrm{HbA1C}$ & 5.6 & 5.2 & 5.0 & 4.9 \\
\hline Serum cholesterol & Normal & Normal & Normal & Normal \\
\hline Serum Calcium & Lowered & Lowered & Normal & $10.12 \mathrm{mg} \%$ \\
\hline Serum Testosterone & 298 & 540 & 168 & 198.78 \\
\hline Vitamin D3(ng/dl) & 21.68 & 13.67 & 12.65 & 17.54 \\
\hline ECG & Low voltage & Low voltage & Normal & Normal \\
\hline
\end{tabular}

\section{RESULT}

In male hypothyroidism presenting without myxoedema and hyperthyroidism with myxoedema

\section{DIS CUSSION}

Thyroid disease affects women more than men i.e.- 5-8 women per men .Male hormones are considered protective against hypothyroidism in male ,low testosterone level predispose for hypothyroidism $7,8,9,10$

Fatigue ,cold intolerance, weight gain are typivcal presentation of hypothyroidism but may present with other associated features -low libido, depression, high cholesterol, loss of executive function, reduced frequency of morning erection, difficulty in growing facial hair, erectile dysfunction and also loss of muscle mass . In addition thyroid hormone can normalize testosterone.

Normally in hypothyroidism myxoedema is a result of accumulation of muco polysaccharide, hyalouric acid and chondroitin sulphuric acid in subcutaneous tissue which exerts osmotic pressure and water retention, solely due to reduced catabolic process . ${ }^{11,12}$

TSH secretion is under the control of Hypothalamus by its hormone Thyrotropin releasing Hormone (TRH) which acts via thyroid receptor activating Adenyl cyclase to increase Cyc AMP 13,14,

Decrease in thyroxin level and increased TSH level affects testosterone which affect basal metabolic rate and alters glucose metabolism leading to accumulation of mucin and retention of Sodium and water in the skin resulting in myxoedema, thus myxoedema in thyroid depends on testosterone value ,as in $3^{\text {rd }}$ and $4^{\text {th }}$ cases presenting with myxoedema and overweight having low TSH and increased thyroxin level with low testosterone while in other 2 cases high testosterone with low thyroxin and high TSH level fails to lower BMR thus fails to promote subcutaneous deposit of mucin, and retention of water and electrolyte. ${ }^{15,16}$ 


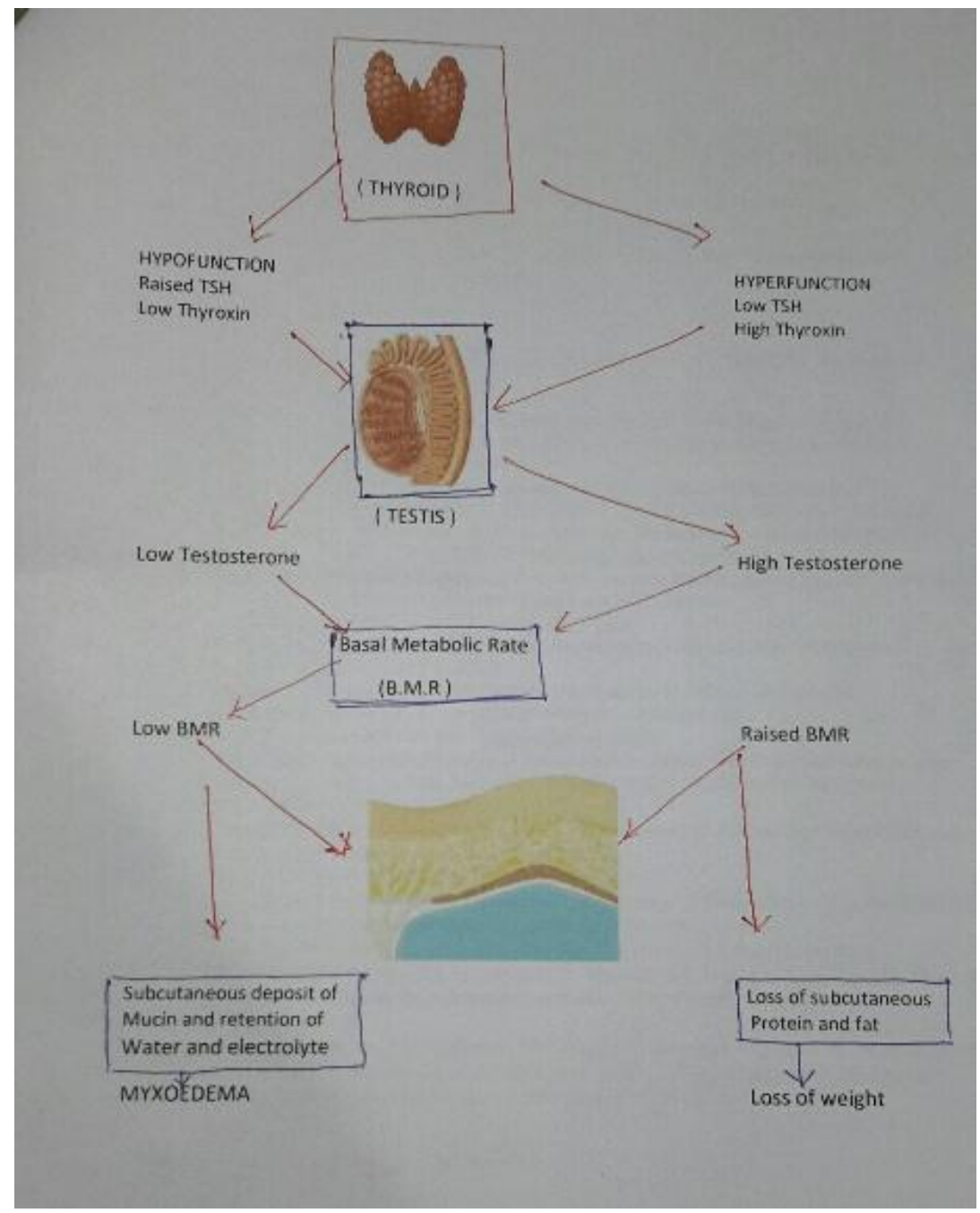

(Schematic presentation of thyroid biokinetics)

\section{CONCLUSiON}

Altered thyroid function alters testosterone secretion in male, which alters BMR thus in case of hypothyroidism raised TSH and low thyroxin (T4), if testosterone remain normal BMR remain unchanged, thus fails to cause subcutaneous deposit of mucin and retention of water and electrolyte, but in case of lowered TSH (,0.1) and high thyroxin (T4) if testosterone level remain lower than normal, then BMR gets lowered and cause subcutaneous deposit of mucin and retention of water and electrolyte, causing myxoedema, Thus conclusively body weight gain or loss in thyroid function alteration is due to altered BMR which depends on gonadal hormone level than on TSH.

\section{REFERENCES}

[1] McAninch EA, Bianco AC (January 2016). "The History and Future of Treatment of Hypothyroidism". Annals of Internal Medicine. 164 (1): 50-6. doi:10.7326/M15-1799. PMC 4980994 PMID 26747302.

[2] Longo, DL; Fauci, AS; Kasper, DL; Hauser, SL; Jameson, JL; Loscalzo, J (2011). "341: disorders of the thyroid gland". Harrison's principles of internal medicine (18th ed.). New York: McGrawHill. ISBN 007174889X.

[3] Kellman, Raphael. "Low Thyroid in Men: Not Just A Women's Issue”. US News \& World Report, 2017. Web. 16 June 2017.

[4] Wortsman J, Moses H, Dufau M. Increased incidence of thyroid disease among men with hypergonadotropic hypogonadism. The American Journal of Medicine.1986;80(6):1055-1059.doi:10.1016/0002-9343(86) 90665-0.

[5] Baskin HJ, Cobin RH, Duick DS, et al; for the American Association of Clinical Endocrinolo-gists.American Association of Clinical Endocrinologists medical guidelines for clinical practice for the evaluation and treatment of hyperthyroidism and hypothyroidism. Endocrine Practice 2002; 8:457-469. 
[6] .Unnikrishnan AG, Menon UV. Thyroid disorders in India: An epidemiological perspective. Indian J Endocrinol Metab. 2011;15:S78-81. [PMC free article] [PubMed]

[7] So, M; MacIsaac, RJ; Grossmann M(August 2012). "Hypothyroidism". Australian Family Physician. 41 (8): 556-62. PMID 23145394. Archived from the original on 2013-05-17.

[8] Hypothyroidism". National Institute of Diabetes and Digestive and Kidney Diseases. March 2013. Archived from the original on 5 March 2016. Retrieved 5 March 2016.

[9] Hollowell JG, Staehling NW, Flanders WD, et al. Serum TSH, T4, and thyroid antibodies in the United States population (1988 to 1994): National Health and Nutrition Examination Survey (NHANES III). J Clin Endocrinol Metab 2002; 87: 489-499.

[10] Wajner SM, Wagner MS, Maia AL. Clinical implications of altered thyroid status in male testicular function. Arq Bras Endocrinol Metabol (2009) 53:976-8210.1590/S0004-273020090008 00011 [PubMed][Cross Ref]

[11] Garber, JR; Cobin, RH; Gharib, H; Hennessey, JV; Klein, I; Mechanick, JI; Pessah-Pollack, R; Singer, PA; et al. (December 2012). "Clinical Practice Guidelines for Hypothyroidism in Adults"(PDF).Thyroid.22 (12): 1200-1235. doi:10.1089/thy.2012.0205. PMID 22954017. Archived (PDF) from the original on 2016-0114.

[12] Dons, Robert F.; Jr, Frank H. Wians (2009). Endocrine and metabolic disorders clinical lab testing manual (4th ed.). Boca Raton: CRC Press. p. 10. ISBN 9781420079364

[13] Singh R, Hamadaa AJ, Agarwal A. Thyroid hormones in male reproduction and fertility. Open Reprod Sci J (2011) 3:98-10410.2174/1874255601103010098 [Cross Ref]

[14] Krassas GE, Poppe K, Glinoer D. Thyroid function and human reproductive health. Endocr Rev (2010) 31:702-5510.1210/er.2009-0041 [PubMed] [Cross Ref]

[15] Krassas GE, Perros P. Thyroid disease and male reproductive function. J Endocrinol Invest (2003) 26:37280 [PubMed]

[16] Krassas GE, Pontikides N. Male reproductive function in relation with thyroid alterations. Best Pract Res Clin Endocrinol Metab (2004) 18:183-9510.1016/j.beem.2004.03.003 [PubMed] [Cross Ref]

Citation: D. Avinash Shankar et al., "An Unusual Presentation of Altered Thyroid in Male", International Journal of Clinical Chemistry and Laboratory Medicine (IJCCLM), vol. 4, no. 2, pp. 11-16, 2018. http://dx.doi.org/10.20431/2455-7153.0402005

Copyright: () 2018 Authors. This is an open-access article distributed under the terms of the Creative Commons Attribution License, which permits unrestricted use, distribution, and reproduction in any medium, provided the original author and source are credited. 